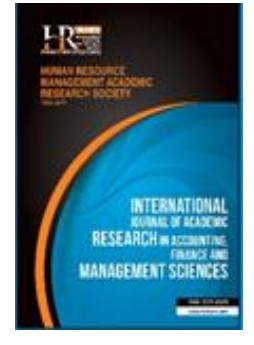

International Journal of Academic Research in Accounting, Finance and Management Sciences

Vol. 10, No.2, April 2020, pp. 9-14

E-ISSN: 2225-8329, P-ISSN: 2308-0337

(c) 2020 HRMARS

www.hrmars.com

To cite this article: Bello, C., Sensini, L. (2020). Financing Decisions of SMEs in the Hotel Industry, International Journal of Academic Research in Accounting, Finance and Management Sciences 10 (2):9-14

\title{
Financing Decisions of SMEs in the Hotel Industry
}

\author{
Ciro Bello ${ }^{1}$, Luca Sensini ${ }^{2}$ \\ ${ }^{1}$ Department of Economics and Statistics, University of Salerno \\ ${ }^{2}$ Department of Management and Innovation System, University of Salerno, ${ }^{2} E$-mail: Isensini@unisa.it
}

\begin{abstract}
The purpose of this paper is to investigate the relationship between investment and financing decisions, focusing on small and medium-sized enterprises (SMEs) operating in the hotel industry. To achieve this purpose, it was carried out a dataset of 72 SMEs (492 firms/year observations). The sample includes Italian SMEs for the period 2010-2015. All the firms included in the sample fall into the definition of SMEs given in European Commission recommendation 2003/361/EC of 6 May 2003. Descriptive statistics, Pearson correlation, and CCA were used. The findings showed the relationship between the groups of balance sheet items. However, results also highlight that firms used their own resources, typically associated with long-term investments, to finance current assets. This behavior may have been caused by environmental and/or market conditions. In particular, the credit crunch that followed the 2008 financial crisis may have affected business behavior.

Key words Financing Decision, Investment, Capital Structure, SME, Hotel Industry.

\begin{tabular}{|c|c|c|}
\hline Received: & 20 Mar 2020 & (C) The Authors 2020 \\
\hline Revised: & 25 Apr 2020 & Published by Human Resource Management Academic Research Society (www.hrmars.com) \\
\hline $\begin{array}{l}\text { Accepted: } \\
\text { Published Online: }\end{array}$ & $\begin{array}{l}05 \text { May } 2020 \\
28 \text { May } 2020\end{array}$ & $\begin{array}{l}\text { This article is published under the Creative Commons Attribution (CC BY 4.0) license. Anyone may } \\
\text { reproduce, distribute, translate and create derivative works of this article (for both commercial and } \\
\text { non-commercial purposes), subject to full attribution to the original publication and authors. The full } \\
\text { terms of this license may be seen at: http://creativecommons.org/licences/by/4.0/legalcode }\end{array}$ \\
\hline
\end{tabular}
\end{abstract}

\section{Introduction}

Starting from the first studies of Modigliani and Miller $(1958,1963)$, over the past 70 years, various theories have been developed to explain capital structure decisions. Among the various theories, the Trade-Off theory (Kraus \& Litzenberger, 1973), that of Pecking Order (Myers, 1984; Myers \& Majluf, 1984), and that of Market Timing (Lucas \& McDonald, 1990) are those most supported by scholars and most used in empirical research. Despite the recognized validity of these theories, some scholars have highlighted that these approaches do not adequately investigate the relationship between investment and financing decisions (Stowe et al., 1980; Carter \& Van Auken, 1990; Helleloid \& Sheikholeslami, 1996).

These studies investigating the relationship between investments and financing decisions have shown that there are some common practices in business behavior. These common practices show that companies tend to finance investments through specific sources of financing (Helleloid \& Sheikholeslami, 1996).

These financial behavior practices can be adopted by firms with varying degrees of intensity. Each company may use only one of these practices and may change its behavior over time (Helleloid \& Sheikholeslami, 1996). Furthermore, the characteristics of the firms, the specificities of the sector, the market trend, and other economic factors can determine different financial behaviors. In this regard, theoretical literature and empirical discoveries on the factors influencing financing decisions have shown that the classification of the sector could be a relevant factor in order to avoid and control possible anomalies between different sectors (Hall et al., 2000; Sensini, 2017). 
In this perspective, the structural and functional characteristics of hotel companies can influence their financial choices, highlighting specific financial behavior. In particular, high fixed costs and high earnings volatility increase financial risk (Devesa \& Esteban, 2011; Lee \& Qu, 2011; Hua et al., 2012). However, the availability of fixed assets can be used as a guarantee for loans and therefore may lead hotel companies to finance such investments with medium/long-term debt, also due to the reduction of the information asymmetry with potential lenders. For these reasons, several authors have highlighted that the financial behavior of hotel companies is specific compared to companies in other sectors [9]. Furthermore, these financial behaviors may change over time (Elgonemy, 2002). Although there are many studies on the determinants of financing behaviors, few articles have focused on this topic in the context of hospitality firms (Sheel, 1994; Dalbor \& Upneja, 2004; Such et al., 2009; Tang \& Jang, 2007; Pacheco \& Tavares, 2017) among others. In the context outlined, the aim of this study is to investigate the financial behavior of hotel firms, limiting the subject of analysis to small and medium-sized firms. The paper focuses on a specific area of interest, the Campania region in South Italy. The period analyzed is 2010-2016. This topic is relevant for several reasons. Firstly, this study can help to understand the financial decisions of hotel businesses. Moreover, the study of the financial behavior of hotel businesses in a specific country may highlight specific factors. Secondly, the tourism sector is a driving factor in Italian GDP, and, in the Campania region, it represents one of the leading sectors for the economy and employment. In addition, the Italian hotel companies are predominantly small and medium-size (95.5\%) (Banca d'Italia, 2019). Therefore, monitoring the economic and financial performances of these companies is important to assess their state of health.

Thirdly, the results of the analysis can help national authorities to identify the most appropriate financial support policies in view of the effects brought about by the health emergency linked to Covid-19. The analysis was developed on a sample of small and medium-sized enterprises. The criteria for including companies in the sample were the following.

Businesses fall into the definition of SMEs provided in the European Commission Recommendation 2003/361/EC of 6 May 2003. Financial statements are available for the entire period under analysis. The financial information for the analysis was collected from the Infocamere database and from the AIDA database of the Van Dijk office (BVD). Overall, the findings showed the relationship between the groups of balance sheet items. However, results also highlight that firms used their own resources, typically associated with long-term investments, to finance current assets. This behavior may have been caused by environmental and/or market conditions. In particular, the credit crunch that followed the 2008 financial crisis may have affected business behavior.

\section{Literature review}

As noted above, some authors have investigated the relationship between investment and financing decisions, showing that there are some common practices in financial behavior. In particular, these common practices are attributable to the following: a) the structure of the assets tends to have the same duration as the maturity of the liabilities; b) some assets, such as accounts receivable, are used to collateral short-term payables; $c$ ) the properties are used as collateral for mortgages or medium/long-term debts; d) high-risk firms prefer to use equity instead of debt; e) companies producing goods have higher inventory levels than service firms (Helleloid \& Sheikholeslami, 1996). Starting from the seminal paper of Stowe et al. (1980), various studies have applied this theoretical approach to investigate the financial behavior of companies in different countries. Van Auken and Tseng (1993) have suggested that the financial behavior of Taiwanese companies is consistent with that of large American companies. However, unlike American firms, Taiwanese companies use short-term debt to finance also medium/long-term activities. This specific behavior could be due to the difficulties of these companies in obtaining medium-long term financing.

Other authors have pointed out that companies' financial behavior tends to adapt to the reference environment (Helleloid \& Sheikholeslami, 1996), to the company's life cycle (Hanks, 1990). Furthermore, other studies have tried to understand the financial behavior of companies by focusing on different sectors (Simonson et al., 1983; Crum et al., 1987). With reference to SMEs, some authors have highlighted that these companies are often unable to finance themselves and therefore resort to external sources of financing. Furthermore, given the financial constraints (Van Auken \& de Lema, 2003), the choice often falls on new capital (Tyejbee \& Bruno, 1983). Other authors have suggested that SMEs use medium and long- 
term debt to finance current assets as well (Carter \& Van Auken, 1990). As previously mentioned, hotel companies have an asset structure that often influences their financial behavior. In fact, on the one hand, the high presence of fixed assets determines the high volatility of the results. On the other hand, the same capital structure can facilitate the granting of loans, acting as collateral (Chen et al., 2014). In the context outlined, the aim of this study is to investigate the relationship between the balance sheet accounts of hotel companies.

\section{Methodology of research}

The financial information was obtained from the Infocamere database as well as the AIDA database of Bureau Van Dijk (BVD). The sample includes Italian SMEs for the period 2010-2015. The criteria for including companies in the sample were the following. Firstly, firms fall into the definition of SMEs given in European Commission recommendation 2003/361/EC of 6 May 2003. Secondly, firms had to have available financial statements for the whole period of study. Thirdly, we excluded companies that were part of a group. In addition, outliers were deleted in order to avoid anomalies of the distribution of each variable.

The final sample is made up of 72 SMEs and covers six years, and so 492 (year/firms) observations were obtained. Agreeing to the main literature (Chen et al., 2014), this study uses canonical correlation analysis (CCA), in order to investigate the relationship between investment and financing decisions.

Applied to the financial statements, this approach allows investigating the relationship between sets of variables and takes into account the interdependencies within the sets. This setting was used to analyze the financial data of hotel firms. However, this approach is not adequate to identify cause and effect relationships. The assets of the balance sheet have been grouped into five series of accounts representing the dependent variables. The groups identified are the following: (1) Cash and securities (CASH); (2) Account receivables (AR); (3) other Current Assets (CA ), computed as current assets - (Cash + AR); (4) Properties, building, plant and equipment (PBPE); (5) other long-term assets (LA), which includes all longterm assets not included in the previous groups.

Liabilities and equity have been grouped into four series of accounts representing the independent variables. The groups identified are the following: (1) Accounts Payable (AP); (2) Current liability (CL), computed as a current liability - Accounts Payable; (3) Long-term liabilities (LTL); (4) Equity (EQ).

\section{Results and discussions}

Table 1 summarizes the results of the descriptive statistics of each group of variables.

Table 1. Descriptive statistics

\begin{tabular}{lcc}
\hline & Mean & Std Dev \\
\hline Asset & & \\
CASH & 7.2 & 18.2 \\
AR & 8.1 & 14.4 \\
CA & 9.9 & 9.3 \\
PBPE & 60.2 & 32.4 \\
LA & 14.6 & 26.9 \\
Liabilities and Equity & & \\
AP & 11.5 & 9.2 \\
CL & 18.2 & 20.3 \\
LTL & 42.4 & 46.2 \\
EQ & 27.9 & 53.2 \\
\hline
\end{tabular}

During the whole period analyzed, medium and long-term assets represent the most significant investment of hotel firms. Among these, PBPE represents approximately $60.2 \%$. The results reinforce the empirical evidence of the literature, confirming that hotel firms are capital intensive and present a high percentage of PBPE. Medium and long-term assets are substantially consistent with sources of financing. Indeed, long-term payables are equal to approximately $42 \%$ of the total liabilities and shareholders' equity is equal to $27,9 \%$ of the total liabilities. Therefore, the investment in fixed assets is financed almost 
completely from sources with adequate characteristics. The results also show a positive net working capital, characterized by a certain presence of liquidity and a low percentage of inventory.

To verify the relationships between the variables, Pearson correlation was applied (Table 2).

Table 2. Pearson correlation

\begin{tabular}{|l|c|c|c|c|c|}
\hline & CASH & AR & CA & PBPE & LA \\
\hline AP & 0.07 & $0.59^{* * *}$ & $0.19^{* * *}$ & $-0.38^{* * *}$ & $0.16^{* * *}$ \\
\hline CL & -0.09 & $0.27^{* * *}$ & $0.18^{* * *}$ & $-0.14^{* * *}$ & 0.02 \\
\hline LTL & $-0.35^{* * *}$ & $-0.25^{* * *}$ & $-0.16^{* * *}$ & $0.27^{* * *}$ & -0.07 \\
\hline EQ & $0.029^{* * *}$ & $-0.14^{* * *}$ & 0.04 & $-0.13^{* * *}$ & 0.03 \\
\hline
\end{tabular}

*** Significant at 0.01; Significant at 0.05; Significant at 0.1 .

With reference to only significant correlations, the examination of table 2 highlights the following.

$A P$ has a positive correlation with $A R, C A$, and $L A$, while it has a negative correlation with PBPE.

$\mathrm{CL}$ has a positive correlation with $\mathrm{AR}$ and $\mathrm{CA}$ and a negative correlation with PBPE. LTL has a positive correlation with PBPE and a negative correlation with CASH and AR. Finally, EQ has a positive relationship with CASH and a negative correlation with PBPE.

These results seem to confirm the interdependencies between the groups of variables. In order to examine the relationship between the two sections of the financial statements, the CCA analysis is applied. Therefore, in consideration of the groups examined, we use four functions. The results are reported in table 3 and show significant correlation levels, in line with the empirical results of other studies (Stowe et al., 1980; Helleloid \& Sheikholeslami, 1996).

Table 3. Significant correlation levels

\begin{tabular}{cccc}
\hline CF & CC & F value & P \\
\hline 1 & 0.665 & 5.04 & $<0.0001$ \\
2 & 0.687 & 4.71 & $<0.0001$ \\
3 & 0.512 & 3.12 & 0.0081 \\
4 & 0.147 & 0.56 & 0.5873 \\
\hline
\end{tabular}

CF: canonical function; CC: canonical correlation; P: probability.

Redundancy indices (Stewart \& Lowe, 1968) are showed in Table 4.

Table 4. Redundancy indices

\begin{tabular}{llccc}
\hline & & ALS & $\mathbf{C ~ R}^{\mathbf{2}}$ & $\mathbf{R i}$ \\
\hline Asset by Liabilities & 1 & 0,2186 & 0.4721 & 0.0941 \\
& 2 & 0.4187 & 0.4362 & 0.1559 \\
Liabilities by Asset & 3 & 0.2091 & 0.2398 & 0.0523 \\
& 1 & 0.2698 & 0.4721 & 0.1198 \\
& 2 & 0.3521 & 0.4362 & 0.2704 \\
& 3 & 0.2712 & 0.2398 & 0.3389 \\
\hline
\end{tabular}

ALS: Average Loading Squared; C R2: Canonical R²; Ri: Redundancy index.

In order to examine the determinants of a significant canonical function, absolute values greater than 0.30 were considered (Table 3). The results shown in table 5 indicate the presence of some significant behavioral models of hotel businesses.

Table 5. Significant behavioral models of hotel businesses

\begin{tabular}{cccccccccc}
\hline & \multicolumn{3}{c}{ Assets } & \multicolumn{4}{c}{ Liabilities and Equity } \\
\hline & CASH & AR & CA & PBPE & LA & AP & CL & LTL & EQ \\
1 & -0.4982 & 0.3321 & 0.9065 & -0.1675 & -0.1657 & 0.0795 & 0.9675 & -0.0715 & -0.3598 \\
2 & 0.4567 & 0.5865 & -0.1439 & -0.8897 & 0.7282 & 0.8124 & -0.1296 & -0.6234 & 0.5276 \\
3 & 0.7674 & -0.0363 & -0.1098 & -0.0894 & -0.4976 & -0.5132 & 0.1078 & -0.6242 & 0.5976 \\
\hline
\end{tabular}


The results indicate a high level of consistency between investments and financial sources. In particular, short-term and fixed assets are financed respectively with short-term and medium/long-term funding sources. The high relationship between PBPE and LTL shows that fixed assets are mainly financed by medium/long-term debt. This evidence suggests that the properties were used as collateral for the loan, reducing the information asymmetry between the creditor and the debtor. The high relationship between $A R$ and AP indicates consistent financial behavior, highlighting that current assets are financed mainly by liabilities characterized by the same maturity.

Finally, the values of CASH and EQ indicate good cash availability and the tendency to use equity to finance investments. This circumstance highlights that hotel companies use their own resources to finance investments and use less leverage. However, EQ is highly associated with short-term activities (CASH and AR) while it is not linked to medium/long-term activities. This circumstance suggests that during the period under analysis the companies used their own resources to finance short-term assets and not fixed assets. This behavior could have been caused by environmental and / or market conditions. Therefore, companies have adapted to changes that have occurred in the reference context.

\section{Conclusions}

This study focused attention on the financial behavior of hotel SMEs, assuming a relationship between investment and financing decisions. To achieve this purpose, we used the balance sheets of a sample of SMEs for the period 2010-2015. The criteria for inclusion of the companies in the sample were explained in section 3. The final sample is made up of 72 SMEs and covers six years, and so 492 (year/firms) observations were obtained.

Agreeing to the main literature (Stowe et al., 1980), this study uses canonical correlation analysis (CCA), in order to investigate the relationship between investment and financing decisions of the hotel firms. The approach used allowed to study the relationship between sets of variables, taking into account the interdependencies within the sets. However, this approach is not adequate for identifying cause and effect relationships. The results have confirmed the relationship between the groups of balance sheet items. However, results also highlight that firms used their own resources, typically associated with longterm investments, to finance current assets. This behavior may have been caused by environmental and/or market conditions. In particular, the credit crunch that followed the 2008 financial crisis may have affected business behavior. Therefore, due to the reduction of external funds, the companies financed the current assets with undistributed profits.

The results of this study help to expand the literature on the subject by highlighting the specific behaviors of hotel businesses. In addition, empirical evidence can assist managers in investment and financing decisions. Finally, the results can help national authorities to identify the most appropriate financial support policies in view of the effects brought about by the health emergency linked to Covid-19. Considering the results that emerged in this study, future research will be aimed at investigating a wider time period and comparing different time periods. This approach will allow a better understanding of the impact of changes in the external environment on the financial behavior of hotel firms.

\section{References}

1. Banca d'Italia (2019), Turismo in Italia: numeri e potenziale sviluppo, Questioni di economia e finanza (occasional paper), n. 505.

2. Carter, R., Van Auken, H. (1990), A comparison of small business and large corporations: interrelationships among position statements, Journal of Business and Entrepreneurship, 2, pp. 73-80.

3. Crum, M. R., Lund, D. B., Van Auken, H. (1987), A CCA of carrier financial strategy: The case of airline deregulation, Transportation Research, 21 (3), pp.179-190.

4. Chen, J., Sanchez, J. A., Sensini, L. (2014), Growth opportunities and ownership structure as determinants of italian firms leverage, ACRMC, pp. 365-386.

5. Darwish, S. (2014). The Role of Universities in Developing Small and Medium Enterprises (SMEs):

Future Challenges for Bahrain. International Business and Management, 8(2), 70-77.

6. Dalbor, M., Upneja, A. (2004), The investment opportunity set and the long-term debt decision of U.S. lodging firms. Journal of Hospitality and Tourism Research 28(3): 346-355. 
7. Devesa, M., Esteban, L. (2011), Spanish hotel industry: indebtedness determinants, Applied Economics, 43(2011), pp. 4227-4238.

8. Elgonemy, A. (2002), Debt-financing alternatives: refinancing and restructuring in the lodging industry Cornell Hotel and Restaurant Administration Quarterly, 43 (2002), pp. 7-21.

9. Hanks, S. (1990), The organizational life cycle: integrating content and process, Journal of Small Business Strategy, 1, pp. 1-13.

10. Hall, G., Hutchinson, P., Michaelas, N. (2000), Industry effects on the determinants of unquoted SME's capital structure. International Journal of the Economics and Business. 7(3), 297-312.

11. Helleloid, R. T., Sheikholeslami, M. (1996), Accounting reporting implications of balance sheet relationships for US multinationals, Journal of International Accounting and Taxation, 5(1), pp. 21-37.

12. Hua, N., Nusair, K., Upneja, A. (2012), Financial characteristics and outperformance, evidence of a contemporary framework from the US lodging industry, International Journal of Contemporary Hospitality Management, 24(2012), pp. 574-593.

13. Kraus, A., Litzenberger, R. H. (1973), A state-preference model of optimal financial leverage The Journal of Finance, 28(4), pp. 911-922.

14. Lee, S., Qu, X. (2011), An examination of the curvilinear relationship between capital intensity and firm performance for publicly traded US hotels and restaurants, International Journal of Contemporary Hospitality Management, 23, pp. 862-880.

15. Lucas, D. J., McDonald, R. L. (1990), Equity issues and stock price dynamics, Journal of Finance, 45(4), pp. 1019-1043.

16. Myers, C. (1984), The capital structure puzzle, The Journal of Finance, 39(3), pp. 574-592.

17. Myers, S. C., Majluf, N. S. (1984), Corporate financing and investment decisions when firms have information that investors do not have Journal of Financial Economics, 13(2), pp.187-221.

18. Modigliani, F., Miller, M. (1958), The cost of capital, corporation finance and the theory of investment. The American Economic Review 48(3): 261-297.

19. Modigliani, F., Miller, M. (1963), Corporate income taxes and the cost of capital: a correction. The American Economic Review 53(3): 433-443.

20. Pacheco, L., Tavares, F. (2017), Capital structure determinants of hospitality sector SMEs, Tourism Economics, Vol. 23 (I), 113-132.

21. Sensini, L. (2017), Capital Structure Determinants in Italian Sme's: An Empirical Study, ICAFR, 124144.

22. Sheel, A. (1994), Determinants of capital structure choice and empirics on leverage behaviour: a comparative analysis of hotel and manufacturing firms. Hospitality Research Journal 17(3), 3-16.

23. Such, M., Parte, L., Garre, A. (2009), The financial structure of the Spanish hotel industry: evidence from cluster analysis. Tourism Economics 15(1), 121-138.

24. Simonson, D. G., Stowe, J. D., Watson, C. J. (1983), A CCA of commercial bank asset/liability structures, Journal of Financial and Quantitative Analysis, 18 (1), pp. 125-140.

25. Stewart, D., Lowe, D. (1968), A general canonic correlation index, Psycological Bullettin, Summer, pp. 160-163.

26. Stowe, J. D., Watson, C. J., Robertson, T. D. (1980), Relationships between the two sides of the balance sheet: a CCA, Journal of Finance, 35(4), pp. 973-980

27. Tang, C. H., Jang, S. (2007), Revisit to the determinants of capital structure: a comparison between lodging firms and software firms International Journal of Hospitality Management, 26, pp. 175187.

28. Tyejbee, T., Bruno, A. (1983), A model of venture capitalist investment patterns, Management Science, 30, pp. 1051-1066.

29. Van Auken, H. E., Tseng, S. (1993), A financial comparison between Taiwanese and US firms: evidence of differential financial strategies, The Journal of Entrepreneurship, 2(1), pp. 59-71.

30. Van Auken, H. E., de Lema, D. G. P. (2003), Financial strategies of Spanish firms: a comparative analysis by size of firm, Journal of Small Business and Entrepreneurship, 17(1), pp. 17-30. 